\title{
ESTIMATING A NATURAL LEVEL OF FINANCIAL DOLLARIZATION IN UKRAINE'
}

\section{KOSTIANTYN KHVEDCHUK ${ }^{a}$, VALENTYNA SINICHENKO ${ }^{a}$, BARRY TOPF}

\author{
${ }^{a}$ National Bank of Ukraine, Kyiv, Ukraine \\ E-mail: Kostiantyn.Khvedchuk@bank.gov.ua \\ E-mail: Valentyna.Sinichenko@bank.gov.ua \\ ${ }^{\mathrm{b}}$ Consultant, International Monetary Fund, Formerly Bank of Israel \\ E-mail: Barrystopf@gmail.com
}

\begin{abstract}
This article overviews the background for financial dollarization in Ukraine. We apply quantitative techniques including both minimum variance portfolio and peer comparison taking into consideration country-specific characteristics to derive an estimated natural dollarization level for Ukraine. The study also discusses potential ways for Ukraine to converge to its natural level, which we estimate at $20 \%$. Additional factors indicate dollarization in the range of $20-30 \%$ as realistic medium-term policy goal.
\end{abstract}
JEL Codes
F41, E58, G11
Keywords
financial dollarization, natural dollarization, euroization, minimum variance portfolio

\section{INTRODUCTION}

Dollarization $^{2}$ is a common problem for emerging economies, and it is one with no simple solution. As such, the topic is a common one for researchers around the world. Ukraine is an example of such an emerging economy, with the hryvnia serving as legal tender in Ukraine since 1996. After a period of hyperinflation in the 1990s, Ukraine has achieved relative stability by keeping inflation to double digits, and more recently to single-digit levels. Partly owing to the rapid pace of inflation over the past nearly 20 years, dollarization is high in Ukraine. It comes in the form of financial dollarization (financial assets and liabilities in foreign currency), real dollarization (defined as the indexation of prices and wages to foreign currency), and currency substitution (as defined by the use of foreign currency for transactions). Distrust in the government, the memory of rapid devaluations, geopolitical threats, and recurrent banking crises have prompted residents to use and hold savings in foreign currency. Moreover, financial markets are underdeveloped, meaning there are limited opportunities to diversify risk.

Dollarization carries consequences to the domestic economy, and it has few benefits. Aleksić et al. (2008) and Yeyati (2006) show that it weakens the interest rate channel of monetary policy transmission. ${ }^{3}$ Excessively dollarized economies have fragile financial sectors because rapid exchange rate movements result in large losses (the so-called balance sheet effect). These economies are therefore prone to banking crises. Their economic growth is also slower and more volatile (Yeyati, 2006). Although financial dollarization promotes financial depth by allowing risk hedging onshore, it has such benefit only in periods of high inflation (De Nicolo et al., 2005). Dollarization promotes investment by lowering interest rates, but it does so at the cost of financial stability. Thus, authorities seek to reduce dollarization to alleviate its mostly negative consequences.

Some degree of dollarization is unavoidable in an open economy, as foreign currency deposits provide a diversification opportunity and can facilitate international trade. Dalgic (2017) views foreign currency deposits as an insurance agreement, where agents who take out foreign currency loans are the insurance providers and the foreign currency depositors insure themselves against devaluation risks.

Nevertheless, excessive dollarization is undesirable. To identify excessive dollarization, we estimate a natural dollarization level. We define it as the dollarization level consistent with the structural characteristics of the Ukrainian economy, assuming a long history of good macroeconomic performance and implementation of appropriate policies. Among structural factors, we consider institutional quality, the geopolitical environment, the high openness of the economy, and the persistence of dollarization due to hysteresis expectations that become embedded in behavior.

This article aims to estimate the natural dollarization level in Ukraine. That natural level will help to measure excess dollarization and serve as a benchmark for de-dollarization policies. However, further empirical research of the drivers of dedollarization is needed to develop de-dollarization measures.

\footnotetext{
${ }^{1}$ The views expressed in this article are solely those of the authors and do not necessarily reflect the view of the institutions that employ the authors.

2 Throughout this article, "dollarization" refers to the use of any foreign currency (EUR or other widely used currency) instead of the domestic currency, rather than specifically the use of USD.

${ }^{3}$ However, according to Reinhart et al. (2003) and Leiderman et al. (2006), disinflation is still possible in highly dollarized economies. The success of Peru, a highly dollarized country, is an example of this.
} 
We contribute to the literature by applying a minimum variance portfolio (MVP) model to Ukraine's macroeconomic data. We then use the output of the MVP model to arrive at a natural dollarization level that takes into account countryspecific factors.

The article is structured as follows: the next section provides an overview of the literature on the determinants of dollarization and approaches to determining the natural dollarization level. Section 3 discusses the trends in financial dollarization in Ukraine and describes its specific factors. Section 4 provides estimates of the natural dollarization level in Ukraine based on the minimum variance portfolio model, a peer review, and estimates from the literature. Finally, Section 5 concludes and discusses de-dollarization policies.

\section{LITERATURE REVIEW}

The determinants of deposit and loan dollarization have been studied extensively. They fall largely into three categories: macroeconomic factors, institutional factors, and prudential regulations.

\section{Macroeconomic Factors}

Portfolio allocation theory under the assumption of uncovered interest parity (UIP) is the most popular concept for dollarization analysis. Ize and Yeyati (2003) introduce a model that derives the minimum variance portfolio (MVP) allocation between local and foreign currency deposits (and loans, respectively) based on expectations of future inflation and exchange rate behavior. The model suggests that financial dollarization does not depend on the levels of inflation and exchange rate but instead on the expectations of their volatility, which is reflected in the MVP ratio. The greater the expected inflation volatility relative to that of the real exchange rate, the greater the share of foreign currency deposits in the MVP. The MVP ratio approximates actual dollarization in many countries (Della Valle et al., 2018).

According to the MVP model, real dollarization is the lower bound of financial dollarization. Contreras et al. (2016) argue that this is the main reason for the relatively high financial dollarization in Peru despite the country's macroeconomic stabilization and the delivery of stable inflation below $5 \%$ for over 15 years. Basso et al. (2010) show that real dollarization, proxied by trade openness, positively affects corporate loan and deposit dollarization.

It follows from the MVP model that the choice of monetary policy and exchange rate regime is key to the dollarization level in the economy. A fixed exchange rate regime aspires to promote macroeconomic stability by stabilizing the exchange rate. Because it lowers exchange rate volatility more efficiently than inflation volatility, the fixed FX regime causes high financial dollarization. As Honig (2009) notes, a fixed FX regime induces borrowers to believe their currency risk is hedged, thus encouraging dollarization.

On the contrary, most countries that target inflation not only aim to bring inflation to the target, but also to keep it in a specified range, thus lowering inflation volatility. Those countries prioritize stabilizing inflation, with exchange rate stabilization a secondary goal. Full-fledged inflation targeting (i.e., one combined with a floating FX regime) should produce the best results in combatting dollarization because it simultaneously lowers inflation volatility and ignores exchange rate volatility. Lin and Ye (2013) have estimated that the introduction of inflation targeting results in, on average, a reduction in financial dollarization of 8 percentage points (pp). Comparing countries with a fullfledged inflation targeting approach to countries with exchange rate targeting offers an even larger estimate of the average treatment effect: $11 \mathrm{pp}$.

Basso et al. (2010) model expands the MVP model by relaxing the UIP assumption. The model predicts that the interest rate differential (i.e., foreign currency minus the local currency rate) is, along with MVP, an important determinant of dollarization in the short-run when UIP does not hold. Therefore, factors that affect interest rate differentials also affect dollarization. Ample access to foreign bank funding, which widens both loan and deposit interest rate differentials, leads to an increase in loan dollarization and a decrease in deposit dollarization. Empirical analyses have confirmed the theoretical predictions for foreign financing of banks and showed that interest rate differential affects dollarization along with MVP. The impulse response functions show that the effect of the interest rate differential is temporary. Urosevic and Rajkovic (2017) also confirm that interest rate differentials only affect dollarization in the short-run.

\section{Structural Factors}

Some authors place government quality on top of their determinants of dollarization. Honig (2009) shows that when controlling for government quality, its effect on dollarization is significant and large while the choice of the exchange rate regime is only marginally important. A hypothetical transition of a country from the bottom to the top of the list in terms of government quality will result in a sizable $35 \mathrm{pp}$ decrease in credit dollarization. De Nicolo et al. (2005) found similar effects stemming from macroeconomic policy credibility and institutional quality.

Adam Honig estimated that the effect of high past inflation is significant and large while the effects of current inflation, depreciation, and MVP are mostly insignificant. This is a sign of the hysteresis of dollarization and explains why many countries have not managed to dampen dollarization even after stabilizing their economies. At first glance, this seems to contradict the MVP model. However, despite a significant decrease in actual inflation variability, the public may still distrust the government's ability to deliver long-run local currency stability, so there may be a systematic gap between expected and actual exchange rate and inflation volatility.

As Basso et al. (2010) note, their model can be used to predict the effect of remittances, although this is not covered in the paper and empirical analysis. Della Valle (2018) shows that remittances positively affect total deposit dollarization.

\section{Prudential Regulations}

Prudential measures are also important determinants of dollarization since they affect interest rate differentials. By favoring foreign currency less than local currency, a regulator can promote de-dollarization. Nevertheless, the short-run nature of the interest rate differential effect implies that the effects of these types of prudential regulations are also short-lived.

In particular, Catão and Terrones (2016) show that imposing higher provisions for foreign currency loans decreased both loan and deposit dollarization. At the same time, increases in marginal reserve requirements on foreign currency deposits decrease deposit dollarization only in 
some cases and do not affect loan dollarization. Moreover, the introduction of higher capital requirements for foreign currency exposures does not affect dollarization on banks' balance sheets. Kokenyne et al. (2010) find that liquid asset requirements imposed on banks' foreign currency assets reduce deposit dollarization, but the effect reverses soon after the measure is introduced.

\section{Estimation of the Natural Dollarization Level}

An MVP model can also be useful for estimating natural dollarization. The MVP approach suggests the optimal currency composition of deposits given the prevailing macroeconomic environment. By assuming that agents expect good macroeconomic conditions in the future, the natural dollarization level can be estimated. However, some factors may induce actual dollarization to depart systematically from the MVP ratio. As discussed in Ize and Yeyati (2003), these include high real dollarization and an imperfectly credible exchange rate targeting regime with episodes of rapid devaluation and high real dollarization. As discussed earlier in this article, actual dollarization may also depart from the MVP due to abundant external bank financing or ample remittances. Lastly, as we discussed previously, low institutional quality and a corrupt government lead agents to disbelieve the government's commitment to deliver macroeconomic stability in the future despite its success in doing so in the past. This will lead to a systemic divergence of the MVP calculated based on actual values of inflation and depreciation from the expectations-based MVP.

Della Valle et al. (2018) are among the pioneers concerned directly with the empirical estimation of the optimal level of foreign currency in an economy. The authors fit a country panel regression of deposit dollarization on a list of dollarization factors, and then compute fitted values using estimated coefficients but replacing actual macroeconomic values with those that reflect a history of good macroeconomic management (i.e., low volatility of inflation and the exchange rate). Using data for 2000-2015, they estimate the natural dollarization level in Ukraine at around $15 \%$.

Geng et al. (2018) found that autonomous euroization for a group of emerging European and Central Asian countries in $2006-2016$ was approximately $15-20 \%$. In this case, autonomous euroization refers to the part of deposit euroization which is not explained by the long-term MVP, the maximum level of inflation, and institutional quality. As the authors note, "this may reflect factors like import companies holding FX deposits as a natural hedge". That refers to the share of foreign currency deposits in the economy to be held in the course of trade and doing business, without other factors. This seems to be close to the lower bound of the natural dollarization level.

\section{BACKGROUND FOR FINANCIAL DOLLARIZATION IN UKRAINE}

Financial dollarization in Ukraine is high but not extreme (Figure 1). In a recent analysis of comparable countries, low-dollarization countries had dollarization levels of $10-20 \%$ over $2009-2016$, while highly dollarized countries had levels of $40-80 \%$ (Della Valle et al., 2018). Ukraine had a dollarization rate of $44 \%$, placing it into the lower end of the highly dollarized range. Moreover, dollarization has decreased over the last three years.

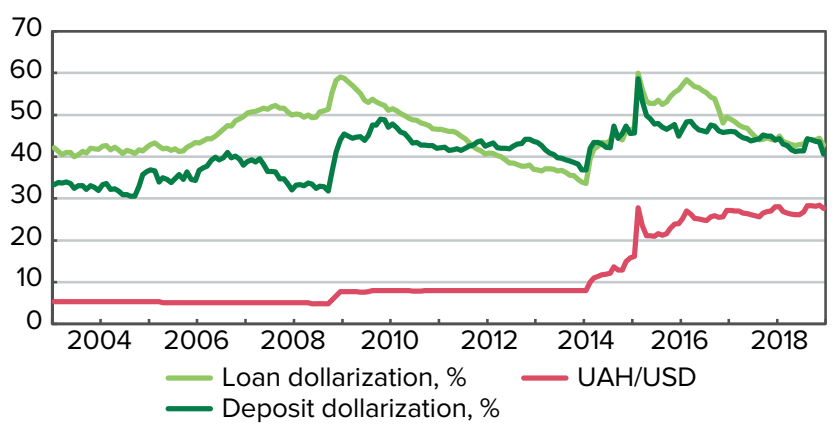

Figure 1. Indicators of Financial Dollarization in Ukraine and the UAH/USD Exchange Rate.

Source: NBU, authors`calculations.

Fundamental factors that contribute to financial dollarization in Ukraine include:

Macroeconomic instability - Ukraine has experienced repeated episodes of high inflation and sharp depreciations of the domestic currency. Several currency crises accompanied by rapid inflation over the past 20 years have revived the memories of the hyperinflation of the early 1990's. Not only the level of past inflation, but also its high volatility drive uncertainty in the future value of the national currency. This results in a deeply rooted "dollarization psychology" which can be self-reinforcing, resulting in a persistent preference for foreign currency over domestic currency.

- Low governance quality - Ukraine is frequently ranked in the lower half in Worldwide Governance Indicators ${ }^{4}$ as measured by control of corruption, rule of law, regulatory quality, and government effectiveness. In recent years, the annexation of Crimea and the military conflict in Eastern Ukraine have increased political instability and raised external threats. This has further eroded trust in the government's economic policy and exacerbated the perception of the instability of the domestic currency. In addition, intrusive and onerous regulation alongside tax avoidance pushes real and financial economic activity abroad, leading to so-called offshorization and subsequent shrinkage of hryvnia funding.

- Monetary policy regime - a de facto fixed exchange rate regime until 2014 has distorted risk perception on both sides of the money market. On the one hand, tail risks of exchange rate fluctuations have contributed to a deterioration of the view of the hryvnia's store of value function. On the other hand, prolonged periods of exchange rate stability caused borrowers to be myopic regarding real foreign currency borrowing costs. As a result, depositors invested in foreign currency as a one-sided bet, while low foreign currency interest rates attracted myopic borrowers. The transition to an inflation-targeting regime in 2015 introduced a clear mandate for the central bank to achieve inflation at a specified range alongside a managed floating exchange rate. However, it will take time for the new policy to gain credibility and for the perceptions of economic agents to change, including their inflation and exchange rate expectations.

- Interest rate differential - In conjunction with devaluation expectations and risk aversion, interest rate differentials can stimulate (de)dollarization in the short-run. Empirically,

${ }^{4}$ More detailed information is available on the website of the World Bank. 
we observe that interest rate parity holds under stable macroeconomic conditions as both interest rate differentials closely followed devaluation expectations in 2010-2013 (Figure 2). However, devaluation expectations have deviated from the interest rate differential since the 2014 crisis. The systematic excess of households' devaluation expectations over the interest rate differential due to the fresh memory among households of the crisis has set back the reduction of deposit dollarization despite relatively high interest rate differential.

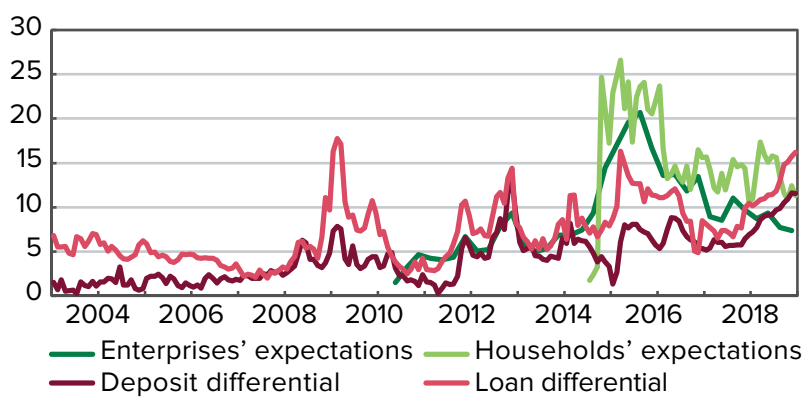

Figure 2. Interest Rate Differentials* and UAH/USD Depreciation Expectations ${ }^{\#}$ \% pa.

Source: GFK, NBU, author's calculations.

${ }^{*}$ Interest rate differential is a difference between hryvnia and foreign currency interest rates.

\# Depreciation expectations is a ratio of 12 month ahead expectation of UAH/USD rate relative to current monthly average rate. Expectation of USD/UAN are based on surveys of households and enterprises.

- External factors - access to foreign funding affects banks' foreign currency positions and their willingness to attract foreign currency deposits. The appetite of Ukrainian banks for foreign funding had been on the rise before the Global Financial Crisis (GFC). The share of foreign liabilities in the total liabilities of deposit-taking corporations (excluding the NBU) surged from 7\% in 2002 to 35\% in 2008 , while foreign assets remained relatively stable. With abundant foreign currency inflows into the banking system from abroad, loan dollarization increased while deposit dollarization declined. The reversal of foreign currency flows since the GFC alongside foreign currency regulations have caused the opposite trend of a decrease in loan dollarization, while deposit dollarization has been relatively stable.

- Real dollarization - although 22 years have passed since the hryvnia became the sole legal tender, the US dollar often serves as a unit of account. Certain goods, such as real estate and vehicles, are de facto indexed to US dollars, whereas de jure transactions are made in hryvnia.

- Structural factors - the high openness of the Ukrainian economy alongside shallow financial markets may contribute to dollarization. International trade as a percentage of GDP fluctuates at around $100 \%$. Remittances from labor migrants abroad reached record high USD 11.1 bn in 2018 , or $8.5 \%$ of GDP. The lack of a market for domestic currency securities is a serious impediment to the development of financial markets and a serious constraint on savers' ability to diversify investments and remain in $\mathrm{UAH}$. Limited access to hedging instruments may force dollarization. However, capital controls are extensive in Ukraine, which holds dollarization back. According to Fernández et al. (2015), Ukraine is part of the "wall" category, meaning it has capital controls for most categories of assets.

\section{NATURAL LEVEL OF FINANCIAL DOLLARIZATION IN UKRAINE}

Although dollarization is considered a negative phenomenon, some share of foreign currency assets is natural for an economy. In our research, we define natural dollarization as the level consistent with good macroeconomic fundamentals conditional on the implementation of proper government policies, while adjusting for structural characteristics and hysteresis. We assume both deposits and loan dollarization will converge to the natural level in the long-run to exclude the possibility of systemic currency mismatches.

One way to look at financial dollarization is that of a riskaverse investor hedging the portfolio against inflation and currency risks. In this case, MVP dollarization is a reasonable share of foreign currency in an investor's portfolio taking into account expected volatilities of inflation and real exchange rate under conditions of UIP.

According to Ize and Yeyati's (2003) MVP model, the share of foreign currency deposits (and loans) corresponding to the minimum-variance allocation approximately equals:

$$
\lambda=\frac{S_{\pi \pi}+S_{\pi s}}{S_{\pi \pi}+S_{s s}+2 S_{\pi s}},
$$

where:

$\lambda$ represents MVP dollarization,

$\pi$ is inflation,

$s$ is the real exchange rate,

$S_{x y}$ is the variance-covariance operator.

We have used historical volatilities of the real exchange rate and inflation as proxies for expected volatilities, which are not observable. In order to compute the variancecovariance matrix for MVP, we tried several options of time series length. The greater the length, the "better" the assumed memory of economic agents. Results for longer time horizons are more persistent. However, the non-linear relationship between exchange rate and prices observed during several crises complicates the interpretation of the results. In the research, we construct two versions of the MVP using rolling periods of 5 and 10 years of data, which respectively suggest 5-year and 10-year MVP dollarization. We exclude crisis periods to obtain more robust results.

The 10-year MVP was in the range of $60-80 \%$ in 2003-2004 due to the hyperinflation of the early 1990s (Figure 3 a, b). However, both MVP ratios decline to $30-40 \%$ in 2005 and then to $18-22 \%$ in 2018. Therefore, the MVP model suggests it is currently optimal to hold $18-22 \%$ of the portfolio in foreign currency.

Actual dollarization coincided with the 5-year MVP in 2004-2008. However, since the GFC, actual dollarization is 15-20 pp above the MVP allocation. The regulatory environment is one explanation for the deviation: the high share of de facto nonperforming loans in foreign currency has driven banks to hold a high share of foreign currency deposits in order to balance foreign currency positions to 

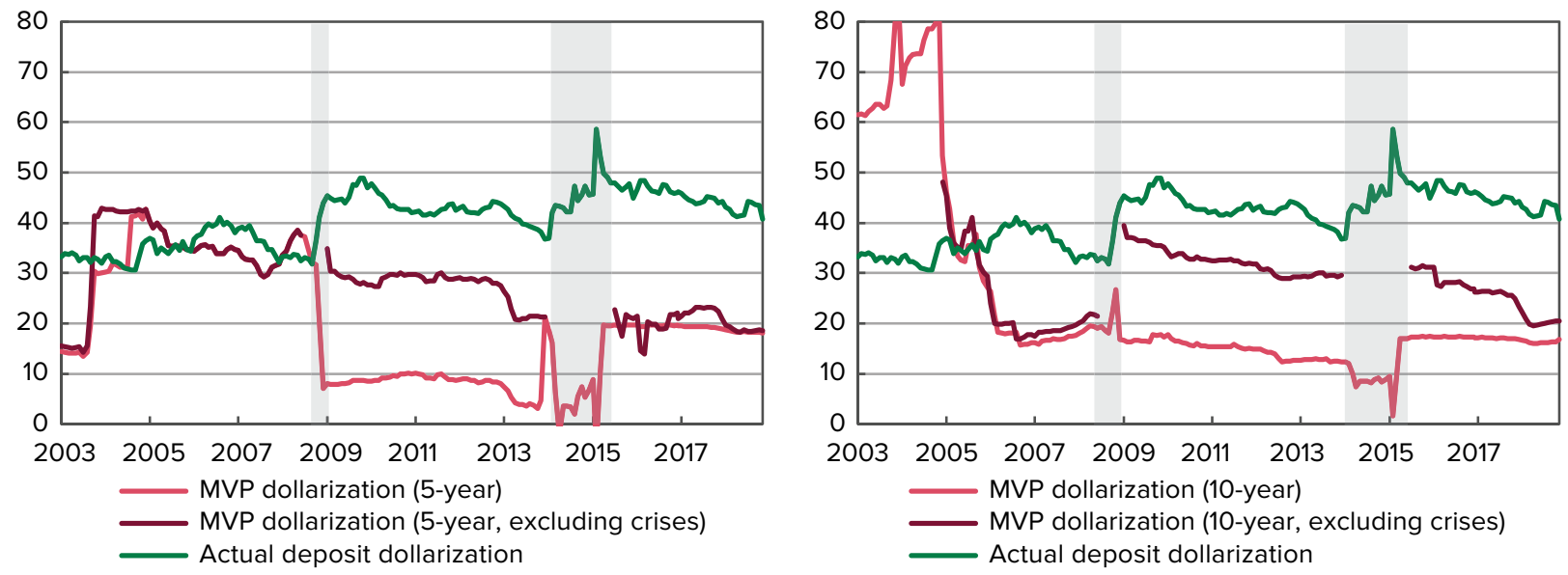

Figures 3a, b. MVP and Actual Dollarization, \%. Grey area depict crises periods.

Source: IMF database, SSSU, authors calculations.

comply with regulations. The devaluation expectations of depositors biased towards downside FX risks, which is not reflected in historical volatilities, are another reason for the deviation of the MVP from actual dollarization.

A peer review is the next step in measuring the level of natural financial dollarization. For comparison, we selected Eastern European countries and countries of the former USSR that have pursued inflation targeting for at least five years (Figure 4). In order to capture the major drivers of dollarization, we show MVP dollarization and regulatory quality alongside deposit dollarization. MVP dollarization is calculated according to (1) based on five years of historical data. As a proxy for regulatory quality, we use the regulatory quality indicator from the Worldwide Governance Database. Regulatory quality captures perceptions of the ability of the government to formulate and implement sound policies and regulations that permit and promote private sector development. ${ }^{5}$

In most cases, actual dollarization reflects regulatory quality - economies with higher regulatory quality have low dollarization and vice versa. Ukraine falls into the group of countries where high dollarization corresponds to low regulatory quality; the group includes Albania, Moldova, Armenia, Turkey, and Romania. MVP dollarization calculated using historical data fairly well approximates actual dollarization in Armenia, Poland, and the Czech Republic, while actual dollarization is well above its MVP value in other countries. In Georgia and Serbia, dollarization has been persistently high even while regulatory quality has improved significantly.

Although the relatively low value of MVP in Ukraine could motivate investment in domestic currency, dedollarization is constrained by a distrust of government policies and high real dollarization. Improved governance quality and its perception by the population is crucial for restoring trust in the domestic currency, but that may still not be enough to decrease financial dollarization. As mentioned in the literature review, real dollarization sets a lower bound for financial dollarization. Although real dollarization is not easy to measure, it can be approximated by the passthrough of the exchange rate on prices. Pass-through in Ukraine is estimated at 0.27-0.28 for the nominal effective exchange rate and at $0.40-0.42$ for USD/UAH exchange rate (Faryna, 2016).

Summing up the different results for natural dollarization in Ukraine (Table 1), we conclude that dollarization in the long term should fall to $20 \%$ given sustainable macroeconomic stability and proper economic policy. As mentioned in the literature review, a recent analysis of panel data indicates $15 \%$ as the optimal deposit dollarization rate in Ukraine, while autonomous dollarization for a group of emerging European and Central Asian countries including Ukraine is estimated at

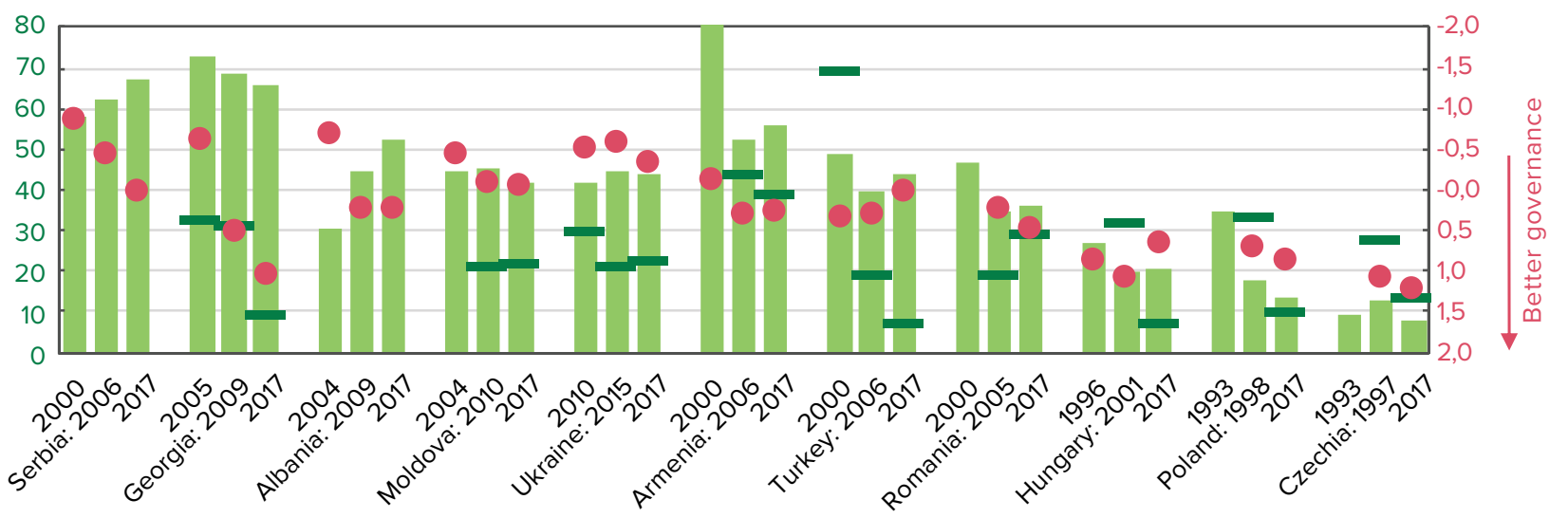

Actual deposit dollarization, \% - MVP dollarization, \% O Regulatory quality (RHS, reverse scale)

Figures 4. Deposit Dollarization, MVP Dollarization, and Regulatory Quality in Selected Countries that Target Inflation. Source: World Bank WGI, central banks' websites, authors' calculations.

Note: Three columns for each country represent data as of several years before IT adoption, year of IT adoption and 2017 respectively.

\footnotetext{
${ }^{5}$ More detailed information is available on the website of the World Bank.
} 
15-20\%. Moreover, different measures of MVP dollarization using historical volatilities show almost the same range at $18-22 \%$. Our peer review illustrates that countries that target inflation and have good regulatory quality alongside a long history of macroeconomic stability can reach dollarization levels of 10-20\% (Poland, the Czech Republic, Hungary).

Table 1. Summary of Estimates of Natural Dollarization Level in Ukraine.

\begin{tabular}{|c|c|}
\hline Source & Estimate \\
\hline Della Valle et al. (2018) & $\begin{array}{l}\text { Benchmark euroization in Ukraine } \\
\text { is } 15 \%\end{array}$ \\
\hline Geng et al. (2018) & $\begin{array}{l}\text { Autonomous euroization in coun- } \\
\text { tries of Europe and Central Asia } \\
\text { (including Ukraine) is } 15-20 \%\end{array}$ \\
\hline MVP dollarization & $18-22 \%$ \\
\hline Peer review & $\begin{array}{l}\text { Actual dollarization in Poland, the } \\
\text { Czech Republic, and Hungary is } \\
\text { in the range of } 10-20 \%\end{array}$ \\
\hline
\end{tabular}

Source: Della Valle et al. (2018), Geng et al. (2018), NBU, other central banks' websites.

All these measures reflect the natural dollarization concept and provide a robust estimate for Ukraine in the range of $10-20 \%$. However, factors that are unlikely to unwind even after the implementation of proper economic policy and after a macroeconomic stabilization, which include geopolitical risks, governance issues and high openness of the economy raise the natural dollarization level for Ukraine to higher bound - around $20 \%$. In our view, taking into consideration dollarization hysteresis, a range of $20-30 \%$ is an achievable medium-term policy goal.

\section{CONCLUSIONS AND POLICY DISCUSSION}

Some degree of dollarization will always be present in an open economy, but excessive dollarization is undesirable. Authorities seek to lower dollarization to reduce vulnerabilities, improve the effectiveness of monetary policy, and help create an environment that will promote balanced growth.

A reasonable benchmark can aid in evaluating the progress of de-dollarization policies. A review of the recent literature, MVP calculations, and a peer review suggest a range of $10-20 \%$. However, the structural characteristics of the Ukrainian economy suggest a higher level of natural dollarization - around $20 \%$. In our view, due to dollarization hysteresis a realistic medium-term policy goal for Ukraine would be to lower financial dollarization to a range of $20-30 \%$. The current dollarization of deposits and loans is around $40 \%$, which we deem excessive.

Any reduction in dollarization is conditional on macroeconomic stability and the development of financial markets, in addition to the implementation of important structural reforms. Furthermore, Kokenyne et al. (2010), Mecagni et al. (2015) argue that a market-driven approach should be the cornerstone of any long-run de-dollarization policy, while forced measures used in isolation from market-based incentives can lead to capital flight and reduced financial intermediation. Still, some countries suffer from dollarization despite achieving the aforementioned conditions. Therefore, identifying effective de-dollarization drivers remains an open topic for further empirical research.

Based on our analysis of key dollarization factors in Ukraine and a literature review, we propose the following components of a market-driven de-dollarization strategy for Ukraine:

- Strengthening institutions and improving governance: protecting creditor rights, ensuring a strong legal system, including effective and impartial judgement and enforcement, equitable taxation policies and enforcement, and reducing corruption.

- Macroeconomic stability: reducing and stabilizing inflation, pursuing a flexible exchange rate regime with twoway risk and moderate volatility, ensuring a real exchange rate that is consistent with fundamentals, building adequate international reserves, and adopting a sustainable and appropriate fiscal stance.

- Ensuring a stable financial system and strong financial institutions.

- Developing financial markets, especially the government bond market in hryvnia and hedging instruments.

Overcoming excessive financial dollarization is not a quick task. According to Honig (2008), hyperinflation promotes dollarization for at least the next 10 years. Moreover, improvements in government quality take time. Dollarization is the outcome of expectations that build upon both the actual macroeconomic environment and a belief in the government's capacity to keep it stable in the future. Reducing real dollarization by improving the credibility of economic policies and particularly the domestic currency is crucial. The government must continuously confirm its commitment to long-term macroeconomic stability by choosing appropriate policies and regulations, and communicating them effectively. 


\section{REFERENCES}

Andres C., Betzer A., Limbach P. (2014). Underwrite Reputation and the Quality of Certification: Evidence From High Yield Bonds. Journal of Banking and Finance, Vol. 40, No. C, pp 97-115. https://doi.org/10.1016/j.jbankfin.2013.11.029

Arrow K. J. (1963). Uncertainty and the Welfare Economics of Medical Care. American Economic Review, Vol. 53, No. 5 , pp. 941-973.

Aleksić, M., Djurdjević, L., Palić, M., Tasić, N. (2008). Interest rate transmission in a dollarized economy: the case of Serbia. Working Paper Series, 15. Belgrade: National Bank of Serbia. Retrieved from http://www.nbs.rs/internet/ latinica/90/90_0/2008_15_MA_LjDj_MP_NT.pdf

Basso, H. S., Calvo-Gonzalez, O., Jurgilas, M. (2011). Financial dollarization: The role of foreign-owned banks and interest rates. Journal of Banking \& Finance, 35(4), 794-806. https://doi.org/10.1016/j.jbankfin.2010.11.018

Catão, L., Terrones, M. (2016). Financial de-dollarization: A global perspective and the Peruvian experience. IMF Working Paper, 16/97. International Monetary Fund. http://dx.doi.org/10.5089/9781484341377.001

Contreras, A., Quispe, Z., Regalado, F. A. (2016). Real dollarization and monetary policy in Peru. Working Paper, 95, p. 16. Peruvian Economic Association. Retrieved from http://perueconomics.org/wp-content/uploads/2014/01/WP95.pdf

Dalgic, H. C. (2018). Financial dollarization in emerging markets: An insurance arrangement. CRC TR 224 Discussion Paper Series, 051. University of Mannheim.

Della Valle, G., Kota, V., Veyrune, R. M., Cabezon, E., Guo, S. (2018). Euroization drivers and effective policy response: An application to the case of Albania. IMF Working Paper, 18/21. International Monetary Fund. http://dx.doi.org/10.5089/9781484338728.001

De Nicoló, G., Honohan, P., Ize, A. (2005). Dollarization of bank deposits: Causes and consequences. Journal of Banking \& Finance, 29(7), 1697-1727. https://doi.org/10.1016/j. jbankfin.2004.06.033

Faryna, O. (2016). Nonlinear exchange rate pass-through to domestic prices in Ukraine. Visnyk of the National Bank of Ukraine, 236, 30-42. https://doi.org/10.26531/ vnbu2016.236.030
Fernández, A., Klein, M. W., Rebucci, A., Schindler, M., Uribe, M. (2015). Capital control measures: A new dataset. IMF Working Paper, 15/80. International Monetary Fund. http://dx.doi.org/10.5089/9781484332177.001

Geng, N., Scutaru, T., Wiegand, J., Carry trade vs. deposit-driven euroization (2018). IMF Working Paper, 18/58. International Monetary Fund. http://dx.doi. org/10.5089/9781484345269.001

Honig, A. (2009). Dollarization, exchange rate regimes and government quality. Journal of International Money and Finance, 28(2), 198-214. https://doi.org/10.1016/j. jimonfin.2008.11.004

Ize, A., Yeyati, E. L. (2003). Financial dollarization. Journal of International Economics, 59(2), 323-347. https://doi.org/10.1016/S0022-1996(02)00017-X

Kokenyne,A.,Ley, J., Veyrune, R.M.(2010). Dedollarization. IMF Working Paper, 10/188. International Monetary Fund. http://dx.doi.org/10.5089/9781455202225.001

Leiderman, L., Maino, R., Parrado, E. (2006). Inflation targeting in dollarized economies. IMF Working Paper, 06/157. International Monetary Fund. http://dx.doi.org/10.5089/9781451864175.001

Lin, S., Ye, H. (2013). Does inflation targeting help reduce financial dollarization? Journal of Money, Credit and Banking, 45(7), 1253-1274. https://doi.org/10.1111/jmcb.12051

Mecagni, M., Corrales. J. S., Dridi, J., Garcia-Verdu, R., Imam, P., Matz, J., ..., Yehoue, E. (2015). Dollarization in sub-Saharan Africa: experience and lessons. Washington: International Monetary Fund. http://dx.doi. org/10.5089/9781498368476.087

Reinhart, C. M., Rogoff, K. S., Savastano, M. A. (2003). Addicted to dollars. NBER Working Paper Series, 10015. National Bureau of Economic Research. Retrieved from: https://www.nber.org/papers/w10015.pdf

Urosevic, B., Rajkovic, I. (2016). Dollarization of deposits in the short and long run: Evidence from CESE countries. Panoeconomicus, 64(1), 31-44. http://dx.doi.org/10.2298/ PAN141230017U

Yeyati, E. L. (2006). Financial dollarization: evaluating the consequences. Economic Policy, 21(45), 62-118. https://doi. org/10.1111/j.1468-0327.2006.00154.x 